the feed water consumption at the inlet of the boiler falls by 2 times, which leads to an increase in the temperature of the LRP steam, the middle and upper radiation parts, screens of the ceiling and rotating chamber; d) to reduce the thermal stratification of the inlet stage of the secondary steam superheater (ППП1), and as a consequence, the pipe wall temperature, it is necessary to divide the ППП1 surface into two packets, installing an intermediate mixing manifold between them with full steam mixing. Bibl. 5, Fig. 13, Tab. 3.

Key words: steam generator, pressure, temperature, boiler, technique, furnace, coal, combustion

\section{References}

1. Rokhman B.B, Dunaevskaya N.I, Vifatnyuk V.G Development of conceptual technical solutions and methods of their implementation in the design of a dust coal steam generator of super-super critical parameters of steam $28 \mathrm{MPa} / 600{ }^{\circ} \mathrm{C} / 600{ }^{\circ} \mathrm{C}$ for a $300 \mathrm{MW}$ energy unit. Part 1. Mathematical description of the working processes, calculation results and boiler arrangements. Energotechnologies and Resource Saving. [Energotekhnologii $i$ resursosberegeniie.]. 2020. No. 1. pp. 419. (Ukr.)

2. Verbovetskiy E.Kh., Zhmerika N.G. Metodicheskie ukazaniya po proektirovaniyu topochnykh ustrojstv energeticheskikh kotlov. [Methodical guidelines for the design of combustion devices for power boilers]. St. Petersburg, 1996. 270 p. (Rus.)
3. Petrenya Yu.K., Gilde E.E., Sudakov A.V., Chizhik A.A., and others. Normy rascheta na prochnost staczionarnykh kotlov i truboprovodov para i goryachej vody (RD 10-249-98). [Standards for calculating the strength of stationary boilers and pipelines of steam and hot water (RD 10-249-98)]. Ser. 20. Iss. 4. Moscow, 2010. 344 p. (Rus.).

4. Kuznetsov N.V., Mitor V.V., and others. Teplovoy raschet kotelnyih agregatov (Normativnyiy metod). [Thermal calculation of boiler units (Normative method)]. Moscow : Energiya, 1973. 296 p. (Rus.)

5. Teplovoy raschet kotlov (Normativnyiy metod). [Thermal calculation of boilers (Normative method)]. St. Petersburg, 1998. 259 p. (Rus.)

Received November 27, 2020

Karp I.M., Academician of the National Academy of Sciences of Ukraine, Doctor of Technical Sciences, orcid.org/0000-0001-5320-0290

The Gas Institute of National Academy of Sciences of Ukraine, Kiev 39, Degtyarevskaya Str., 03113 Kiev, Ukraine, e-mail: karpkiev@gmail.com

\title{
Hydrogen in municipal energy
}

The use of hydrogen in the municipal energy sector is currently inappropriate due to its high cost. Production of hydrogen by electrolysis requires more energy than it is emitted during its combustion. Thermophysical properties of hydrogen and natural gas are compared. Heat value of hydrogen in a unit of volume is 3.3 times lower than that of methane. The cost per unit of energy in hydrogen is more than 10 times higher than in natural gas. Distribution gas networks are not suitable for transportation of pure hydrogen. The possibility of transporting hydrogen in mixtures with natural gas is being studied. The efficiency of fuel use in a heating gas boiler decreases with increasing hydrogen concentration in a mixture with natural gas up to $50 \%$. The concentration of nitrogen oxides does not depend on the hydrogen content in the mixture. Bibl. 4, Table 1.

Key words: hydrogen, thermophysical properties, effectivnes.

The use of hydrogen in the global power industry is considered one of the most promising areas of transition to carbon-free energy. A number of programs at the state level have been adopted in 
the world in this direction. Some countries (Japan, Austria) even declared a full transition to this energy carrier and declared themselves as "hydrogen energy" countries. However, if you look at the world map, you will see that this applies mainly to rich countries.

Numerous hydrogen energy projects consider its application as an energy accumulator, transport motor fuel, reducing gas and metallurgy fuel as a means of energy transmission over a distance. This refers to the so-called "green hydrogen" produced by electrolysis. Much less attention is paid to studying its application as a source of energy in the municipal sphere. Public utilities are socially oriented and projects in this area are very sensitive to the cost of energy resources, their performance characteristics and environmental friendliness.

The production of hydrogen by electrolysis uses more energy than can be obtained by burning it. At least $4-5 \mathrm{kWh} / \mathrm{m}^{3}$ is consumed, $3 \mathrm{kWh} / \mathrm{m}^{3}$ is obtained. Electric energy in the cost of electrolysis is $85 \%$. It is believed that in order to meet the Green Deal conditions, electricity for electrolysis must be clean. This is atomic energy or from renewable energy sources. In Ukraine, one $\mathrm{kWh}$ of RES costs on average 4.5 times more expensive than from traditional sources on the energy mar- ket. Taking into account that the calorific value of hydrogen is 3.3 times less than that of methane, we get that one calorie in hydrogen costs more than 10 times more expensive than in natural gas. State Company "Energoatom" supplies electricity to the combined energy market at a price from 0.8 to 1.15 UAH. Here the ratio is slightly better.

Russian magazine [1] with reference to the English edition of Energy Monitor writes that the intention of "direct" use of $\mathrm{H}_{2}$, ie replacement of boilers running on natural gas with hydrogen is characterized by the English idiom "to sell someone a pup" ("to sell a puppy"), which means a situation where under the guise of one product is sold to another. In other words, the gas industry is trying to sell the idea that it is possible to replace fossil gas with hydrogen using the existing gas distribution infrastructure.

In addition to economic considerations, one should take into account such properties of hydrogen as wide explosive range (3-85\% in the mixture with air; for methane it is 5-15\%), high flame propagation rate, corrosiveness. These properties require special measures to be taken for its transportation, storage and use, especially in mass use for domestic purposes. The main thermophysical properties of hydrogen are given in Table [2].

\section{Thermophysical characteristics of hydrogen}

\begin{tabular}{|c|c|c|c|c|c|c|c|}
\hline $\begin{array}{c}\text { Flammable } \\
\text { gas }\end{array}$ & $\begin{array}{c}\text { Lower heat of } \\
\text { combustion } \mathrm{Q}_{1}, \\
\mathrm{~kJ} / \mathrm{m}^{3} \\
\left(\mathrm{kcal} / \mathrm{m}^{3}\right)\end{array}$ & $\begin{array}{c}\text { Higher heat of } \\
\text { combustion } \mathrm{Q}_{\mathrm{h}}, \\
\mathrm{kJ} / \mathrm{m}^{3} \\
\left(\mathrm{kcal} / \mathrm{m}^{3}\right)\end{array}$ & $\begin{array}{c}\mathrm{Q}_{\mathrm{h}} / \mathrm{Q}_{\mathrm{l}}, \\
\%\end{array}$ & $\begin{array}{c}\text { Ignition } \\
\text { tempera- } \\
\text { ture, }{ }^{\circ} \mathrm{C}\end{array}$ & $\begin{array}{c}\text { Ignition lim- } \\
\text { its in mixture } \\
\text { with air, \% }\end{array}$ & $\begin{array}{c}\text { Calorimeter. } \\
\text { combustion } \\
\text { temperature, } \\
{ }^{\circ} \mathrm{C}\end{array}$ & $\begin{array}{c}\text { Norm. flame } \\
\text { propagation } \\
\text { speed*, } \\
\mathrm{m} / \mathrm{sec}\end{array}$ \\
\hline $\mathrm{CH}_{4}$ & $35739(8550)$ & $39500(9450)$ & 111 & 645 & $5-15$ & 2211 & 0.28 \\
\hline $\mathrm{H}_{2}$ & $10800(2580)$ & $12767(3054)$ & 118 & 510 & $3.3-81,5$ & 2380 & 1.6 \\
\hline
\end{tabular}

* Other sources give values for $\mathrm{CH}_{4}-0.37$; for $\mathrm{H}_{2}-2.7-4.8 \mathrm{~m} / \mathrm{sec}$.

However, it is very likely that not these properties of hydrogen are an obstacle to the widespread use of hydrogen in the municipal energy sector. By introducing strict rules for handling of hydrogen and selection of appropriate materials for pipes, it would be possible to ensure its safe use. Finally, it is not necessary to use $100 \%$ hydrogen; it is possible to use its mixtures with natural gas, the requirements to which are less stringent.

The main constraint to the wide use of $\mathrm{H}_{2}$ is its high cost. The International Energy Agency believed that by 2030 green hydrogen will cost 0.1 euro per $\mathrm{kWh}$ at the place of its production, i.e. 0.3 euro per $1 \mathrm{~m}^{3}$. Close estimates were presented by the UK Committee on Climate Change. In bringing to Ukrainian prices, this means that $1 \mathrm{~m}^{3}$ of hydrogen will cost about 10 hryvnia. This cost significantly exceeds the cost of natural gas in the Teplokommunenergo system. The same price for energy in hydrogen as in natural gas will be 56 times more expensive than in natural gas.

Objectivity requires that experts also consider other sources of hydrogen, such as those derived from products of gasification of carbon-containing substances or enzymatic digestion of waste. It is believed that the hydrogen obtained in this way will not be as expensive as electrolysis. Power Engineering International magazine chose 5 hydrogen projects among many, which, according to the magazine, can change the general picture in hydrogen energy [3]. One such project is the construction of the world's largest plant in Lancaster, California, to produce hydrogen from the products of paper waste gasification. Plastics, tires and textiles 
can also be gasified at the plant. It is claimed that this method generates "greener than green" hydrogen. Hydrogen is 5-7 times cheaper than electrolysis and competes with "grey" hydrogen. Commissioning of the plant into commercial operation is scheduled for 2023.

Despite some uncertainty in the sources of hydrogen - renewable energy sources, nuclear power plants, waste gasification - and its high cost, projects on the use of hydrogen or its mixtures with natural gas in the municipal energy sector are already underway. The HyDeploy project in England is well known [4]. The project demonstrated the injection of $20 \%$ hydrogen into the gas distribution network of Keele University, which supplies gas to 30 university and 100 residential buildings. This is still the highest concentration of hydrogen in the mixture in Europe. The safety of this mixture in the network has been proven. Similar projects are underway in France and Scotland.

A similar project is being implemented in Ukraine on the initiative and financial support of the Regional Gas Company, which unites several regional gas companies.

Tests were conducted on gas landfills that fully simulate local gas distribution networks. The density tests showed that the existing networks are not suitable for transportation of pure hydrogen. At 4 bar pressure after 14 hours of exposure, the pressure drop in the test area was $46 \%$. Typical leak points were threaded and coupling joints, despite the use of modern sealing materials, and what is surprising-welded seams, including factory-made. At a pressure of $100 \mathrm{~mm}$ water. ste. leaks were $0.01 \%$ per hour, which is within the norm for natural gas. The study of leaks of the mixture with concentrations of hydrogen $10-50 \%$ is currently underway.

The efficiency and environmental friendliness of gas mixtures in household gas appliances - gas stoves and heating boilers - were studied. Gas stove of Ukrainian production "GRETA" and 2-circuit boiler MICRA DUO CS24 by RЦDA with capacity $25 \mathrm{~kW}$ were studied.

Both devices are equipped with atmospheric burners. The range of hydrogen concentration change is from 10 to $50 \%$. In this range, there is stable combustion without flame slippage or bursting. At increase of hydrogen concentration the efficiency of gas stove slightly increases (by 2-3\%) and reaches the regulatory maximum $-58 \%$. At increase of heat load by 2-2.5 times the efficiency on all types of fuel is predicted to decrease to $35-47 \%$, and on natural gas the decrease is more.

The efficiency of the heating boiler when operating on natural gas increases from 85 to $91.5 \%$ and decreases to $82-88 \%$ with an increase in the concentration of hydrogen in the mixture to $50 \%$ within the same load limits. The concentration of $\mathrm{CO}$ in the flue gases in the mixture is 2 times lower than in the gas. Concentration of $\mathrm{NO}_{\mathrm{x}}$ reduced to $3 \%$ of oxygen does not depend on the type of fuel and is about $80 \mathrm{ppm}$.

In conclusion, it should be said that significantly, 5 times more effective way to achieve the objectives of carbon-free energy is the use of renewable energy for heat pump drive.

The use of hydrogen as an energy accumulator can be a promising trend in thermal power engineering. For example, in the case of the hydrogen "House of the Future", which has been inhabited in Switzerland for several years and is fully autonomous, hydrogen is used as an intermediate substance in which energy is stored. But the end consumers who live in their apartments do get readymade heat and electricity, not hydrogen.

The question of using hydrogen for heating was studied in detail by the German institute Fraunhofer IEE and came to similar conclusions.

\section{Conclusion}

The results of the study are unambiguous: hydrogen is not suitable for heating buildings. The amount of green electricity needed to produce green hydrogen for this purpose is 500-600 percent more than the amount needed to power an equivalent number of heat pumps.

\section{References}

1. Hydrogen for heating buildings is an unreasonable decision. Santekhnika. Otopleniie. Konditsionirovaniie. 2020. No. 10. P. 5-8. (Rus.)

2. Karp I.M. Hydrogen: properties, production and peculiarities of the use. Energotekhnologii $i$ resursosberegeniie. 2020. No. 2. pp. 4-13. DOI https://doi.org/10.33070/etars.2.2020.01/(Ukr.)

3. Hydrogen: Five potential game-changers to watch. PEI, October 29, 2020.

4. Tommy I. HyDeploy: The UK's First Hydrogen Blending Deployment Project. Clean Energy, 2019, Vol. 3, Iss. 2, pp. 114-125. https://doi.org/10.1093/ce/zkz006

Received November 25, 2020 
Kapn I.M., докт. техн. наук, акад. НАН Украӥни, оrcid.org/0000-0001-5320-0290 Інститут газу НАН України, Київ

вул. Дегтярівська, 39, 03113 Київ, Украӥна, е-таil: karpkiev@gmail.com

\section{Водень у комунальній енергетиці}

Використання водню в комунальній енергетиці в даний час недоцільно через його високу вартість. На виробництво водню електролізом потрібно більше енергії, ніж виділяється при його спалюванні. Порівняно теплофізичні властивості водню та природного газу. Теплотворна здатність водню в одиниці об'єму у 3,3 рази нижче, ніж метану. Вартість одиниці енергії у водні більш ніж у 10 разів вище, ніж у природному газі. Розподільні газові мережі непридатні для транспортування чистого водню. Можливість транспортування водню у сумішах з природним газом вивчається. Ефективність використання палива в опалювальному газовому котлі зі збільшенням концентрації водню у суміші з природним газом знижується до $50 \%$. Концентрація оксидів азоту не залежить від вмісту водню у суміші. Бібл. 4, табл. 1.

Ключові слова: водень, теплофізичні властивості, ефективність.

\section{Список літератури}

1. Водород для отопления зданий - необоснованное решение. Сантехника, Отопление, Кондиционирование. 2020. № 10. С. 5-8.

2. Карп I.М. Водень: властивості, виробництво та особливості використання. Енерготехнології та ресурсозбереження. 2020. № 2. C. 4-13. DOI https://doi.org/10.33070/etars.2.2020.01
3. Hydrogen: Five potential game-changers to watch. PEI, October 29, 2020.

4. Tommy I. HyDeploy: The UK's First Hydrogen Blending Deployment Project. Clean Energy, 2019, Vol. 3, Iss. 2, P. 114-125. https://doi.org/10.1093/ce/zkz006

Надійшла до редакції 25.11.20

Карп И.Н., докт. техн. наук, акад. НАН Украины, orcid.org/0000-0001-5320-0290 Институт газа НАН Украины, Киев ул. Дегтяревская, 39, 03113 Киев, Украина, е-таil: karpkier@gmail.com

\section{Водород в коммунальной энергетике}

Использование водорода в коммунальной энергетике в настоящее время нецелесообразно из-за его высокой стоимости. На производство водорода электролизом требуется больше энергии, чем выделяется при его сжигании. Сравнены теплофизические свойства водорода и природного газа. Теплотворная способность водорода в единице объема в 3,3 раза ниже, чем метана. Стоимость единицы энергии в водороде более чем в 10 раз выше, чем в природном газе. Распределительные газовые сети непригодны для транспортировки чистого водорода. Возможность транспортировки водорода в смеси с природным газом изучается. Эффективность использования топлива в отопительном газовом котле с увеличением концентрации водорода в смеси с природным газом снижается до 50\%. Концентрация оксидов азота не зависит от содержания водорода в смеси. Библ. 4, табл. 1.

Ключові слова: водород, теплофизические свойства, эффективность 